\title{
Sovereign external debt and private sector entry in international financial markets ${ }^{1}$
}

\section{Michał Brzozowski², Joanna Siwińska-Gorzelak ${ }^{3}$}

\begin{abstract}
The aim of this paper is to shed light on the public and private sector interdependencies in the international financial market. Using annual data on sovereign and private sector external indebtedness for 95 emerging and developing countries in the 1970-2012 period it looks at the relationship between the level and structure of public external debt and the likelihood of private sector entry in international bond and loan markets. The private sector entry in the offshore loans and bonds markets is shown to be conditional on the amount of public sector external debt. The relationship is complex but in general the saturation of the financial market with external government liabilities renders the private sector entry into the bonds' market more difficult.
\end{abstract}

Keywords: external debt, sovereign, private sector.

JEL codes: F34, H63.

\section{Introduction}

The research on external debt occupies a significant place in the economic literature yet most studies have concentrated on sovereign or private external liabilities, treating them as distinct phenomena, possibly only loosely linked. This paper sheds light on some aspects of the public and private sector interdependencies in the international financial market.

More precisely the research question is whether the private sector's decision to enter the international bond and loan market depends on the amount and structure of public external debt. To gain more insight into the relationship the public and publicly guaranteed external debt by type of instrument is disag-

\footnotetext{
${ }^{1}$ Article received 8 December 2017, accepted 30 March 2018.

The support of the National Science Center, grant no. UMO-2016/21/B/HS4/00669 is gratefully acknowledged.

${ }^{2}$ University of Warsaw, Faculty of Economic Sciences, Department of Macroeconomics and Foreign Trade Theory, Długa 44/50 Warsaw, Poland.

${ }^{3}$ University of Warsaw, Faculty of Economic Sciences, Department of Macroeconomics and Foreign Trade Theory, Długa 44/50 Warsaw, Poland, siwinska@wne.uw.edu.pl.
} 
gregated. The relationship between the private sector entry into the bond and loan markets and public external debt is found to display a complex pattern, but in general it is concluded that saturation of the financial market with external government liabilities renders the private sector entry into the bonds' market more difficult. This is a novel conclusion as this issue has not been studied in the literature before; yet the authors believe that it offers a valuable extension of our knowledge on the macroeconomic impact of external public debt. The study also allows the formulation of interesting policy conclusions regarding the structure of sovereign indebtedness that has the smallest negative repercussions with regards to the private sector's entry in to foreign financial markets.

The paper is structured as follows. The first section is devoted to the literature review on the nexus between the private and public sector presence in the global financial market. Section 2 shows the evidence on the influence of public sector debt on the probability of private sector entry in the international bonds and loans markets and the last section concludes.

\section{Review of the literature}

The literature on the determinants of private sector external debt and the issue of the probability of entry in the international financial market is scarce. Reference is made to capital structure theories to improve our understanding of foreign debt issuance. They point to several factors that affect the decision of private companies to seek external finance.

According to the static trade-off theory firms increase foreign debt to exploit cost advantages arising from lower interest rates and preferential tax treatment. Gozzi, Levine, Peria and Schmuckler (2015) compared the characteristics of firms' debt issues in domestic and international markets since the 1990s. They found that issues abroad have yield spreads that are on average about 16 basis points lower than those of issues at home even if domestic markets are more developed. In the same vein borrowing-cost savings associated with deviations from uncovered interest parity were found by Habib and Joy (2010) to influence the choice of debt issuance currency.

Firms from emerging and developing countries can face external finance rationing in underdeveloped domestic financial markets. The affluence of the international financial market can be more tempting than the low cost of foreign borrowings. The insufficient depth and liquidity of local financial markets was the main motive behind offshore corporate bond finance in Asian emerging markets studied in Mizen, Packer, Remolona and Tsoukas (2012).

Due to the so called 'original sin' foreign debt of emerging economies is usually denominated in foreign currencies which makes it attractive for firms exposed to exchange rate risk. In other words, corporations characterized by a high degree of foreign-currency exposure can tap international financial mar- 
kets to hedge against exchange rate risk. A positive correlation between various proxies for foreign-exchange exposures, such as the fraction of foreign sales or foreign subsidiaries and the level of foreign debt has been detected in a number of developed countries, inter alia in the United States (Allayannis \& Ofek, 2001), Denmark (Aabo, 2006) and Finland (Keloharju \& Niskanen, 2001).

The decision to seek finance abroad can also be analyzed in the broader context of a company's hierarchy of financing sources emphasized in the pecking order theory of Myers and Majluf (1984). The pecking order hypothesis posits that firms prefer to finance with retained earnings and only less profitable ones seek external financing in the debt market. Once debt markets are exhausted firms would turn to local equity markets. According to Allayannis, Brown, and Klapper (2003) local external financing is preferred and entry in to foreign debt and equity markets is forced by the limited accessibility of funds in the respective domestic market segments.

The literature reviewed so far has focused on the external debt from bonds. Another, relatively scarce research, focuses on cross-border bank flows and studies the determinants of the magnitude of bank lending. A popular pushpull factors analysis conducted by Jeanneau and Micu (2002) revealed that both types of factors determined international bank lending to the largest countries in Asia and Latin America. The internal macroeconomic conditions in the host countries (Garcia-Herrero \& Martinez-Peria, 2005; Hernandez, Mellado, \& Valdés, 2001) as well as their counterparts in the home countries (Goldberg, 2001) were found to exert a significant influence on bank lending to emerging markets. Moreover push and pull factors related to risk aversion and financial volatility helped Herrmann and Mihajlek (2010) to explain cross-border bank flows from 17 advanced economies to 28 emerging markets in Asia, central and eastern Europe and Latin America. The factors affecting the decision to enter the international loan market have not received any attention in the literature as yet.

In this paper the focus is on the decision of the private sector to enter international bond and loan markets. The influence of the push factors, that is the costs and availability of domestic financing are examined. The pull factors, such as the probability of debt repayment, which affect the willingness of foreign lenders to buy domestic corporate bonds or give loans to the private sector are also investigated. The set of likely determinants of the entry decision is extended to include the level of public external debt which has not been studied in the articles reviewed. According to the main hypothesis posited in the paper:

H1: The sign of the relationship between private sector entry and the level of public external debt is ambiguous. It can be argued that there are two forces at work on the side of foreign lenders which can be regarded as pull factors with respect to sovereign debt. 
On the one hand the repayment on time and in full of sovereign external liabilities establishes and enhances the creditworthiness of a country and helps the private sector to improve its credit standing and to borrow abroad. Thus one can expect a positive relationship between the level of external public debt and the probability of international financial market penetration by private sector borrowers. In other words the timely servicing of public debt obligations can pave the way for private borrowers. Conversely an increase in sovereign credit risk raises corporate credit risk as was documented by Augustin, Boustanifar, Breckenfelder and Schnitzler (2016) for Europe and Cavallo and Valenzuela (2010) for emerging markets. Das, Papaioannou and Trebesch (2010) and Esteves and Jalles (2016) confirm that there is a negative relationship between the sovereign default risk and the volume of external financing available to the private sector. In a related piece of research Mohapatra, Nose and Ratha (2017) examine the factors that affect the gap between sovereign and private ratings and find that riskier global economic conditions strengthen the links between non-sovereign and sovereign ratings.

On the other hand high external public indebtedness can feed the appetite of foreign investors for bonds issued by and loans extended to the residents of a country. Foreign investors can regard public and private sector foreign liabilities as substitute assets in their portfolios. Higher external public debt can thus crowd-out private borrowings if diversifying investors do not wish to allocate a greater part of their financial wealth to a country's liabilities. The substitutability of various types of public external debt for private external debt is discussed in Brzozowski and Siwińska-Gorzelak (2016). Moreover a high level of public external debt raises concerns of sovereign default and can be an obstacle to private sector entry in the international financial market given the costs of default. Thus the impact of external public debt on the entry of private agents in the international financial market can go either way and deserves empirical scrutiny.

\section{Is public debt paving or blocking the way for private borrowers?}

The empirical analysis of the interplay between foreign public and private borrowing begins with a +consideration of the primary decision of the private sector to enter (re-enter) international financial markets. The private sector entry decision is not examined - that is attention is not paid to the number of agents involved and the amount they borrow. Instead the study concentrated on the likelihood of private residents inaugural participation in the international financial market. The private sector is classified as to whether to initiate or to resume external borrowing if the value of loans/bonds in a given year turns positive while it was equal to zero in the preceding year. More specifically two 
dummy variables are constructed pertaining to non-guaranteed long term debt from bonds and long term commercial bank loans, denoted bond_png_dum and bank_png_dum, respectively, defined as follows:

bond_png_dum ${ }_{t}= \begin{cases}1 & \text { if bond } \\ 0 & \text { otherwise }\end{cases}$

bank_png_dum $w_{t}= \begin{cases}1 & \text { if bank_png_stock } \\ 0 & \text { otherwise }\end{cases}$

where bond_png_stock ${ }_{t}$ and bank_png_stock denote the stock of outstanding long term nonguaranteed debt from bonds and commercial bank loans in period $t$. All variables are in real terms, that is the original series in current US dollars have been deflated with the aid of the US CPI price deflator. The annual data on the debt levels comes from the Joint External Debt Hub - jointly developed by the Bank for International Settlements, the International Monetary Fund, the Organization for Economic Cooperation and Development and the World Bank.

The value of government debt is deliberately expressed in absolute terms rather than as a percentage of GDP on the premise that a foreign investor's decision to hold private sector debt from loans and bonds depends on the amount of external public debt in their portfolios. From the perspective of asset diversification the stock of external debt as a fraction of the GDP of the borrower's country is far less important than its weight in a lender's portfolio which depends on its absolute value.

In line with the hypothesis advanced in section 1 the relationship between the stock of external public debt and the probability of private sector entry in the global financial market is likely to be non-linear. The positive reputation enhancing effect of public debt can be offset by the negative crowding-out effect in the case where public and private liabilities are substitutable assets in the eyes of foreign investors. To deal with nonlinearity regression models are based on fractional polynomials functions which increase the flexibility of quadratic or cubic functions popular in data analysis.

The fractional polynomial of degree $m$ has $m$ integer or fractional powers $p_{1}<\ldots<p_{m}$ and can be written as

$$
\beta_{0}+\beta_{1} x^{\left(p_{1}\right)}+\beta_{2} x^{\left(p_{2}\right)}+\Lambda+\beta_{m} x^{\left(p_{m}\right)}
$$

where

$$
x^{(p)}=\left\{\begin{array}{lll}
x^{p} & \text { if } & p \neq 0 \\
\log x & \text { if } & p=0
\end{array}\right.
$$

The permitted powers are usually restricted to $\{-2,-1,-0.5,0,0.5,1,2,3\}$ and they can be repeated. For instance a fractional polynomial of second degree with repeated powers of -0.5 takes the form 


$$
\beta_{0}+\beta_{1} x^{-0.5}+\beta_{2} x^{-0.5} \log x
$$

The powers and the coefficients must be estimated from the data and the former are selected on the basis of a minimization of the deviance which is defined as minus twice the log likelihood. Royston and Sauerbrei (2008) suggest that a fractional polynomial of second degree is usually sufficient and their suggestion is followed in this paper. Thus the impact of the level of public debt is modelled by means of an equation (3) with unique or repeated powers that yield the lowest deviance.

As already indicated the key covariates are the levels of public and publicly guaranteed external debt disaggregated by type of instrument. Four types of external public sector liabilities have been distinguished. The variable called bond_ppg denotes public and publicly guaranteed debt from bonds, while bank_ppg are commercial bank loans from private banks and other private financial institutions. Public and publicly guaranteed debt from official creditors which includes loans from international organizations (multilateral loans) and loans from governments (bilateral loans) is labelled official_ppg. Finally the variable other_ppg represents public and publicly guaranteed other private credits from manufacturers, exporters and other suppliers of goods and bank credits covered by a guarantee of an export credit agency. Each of the above are entered as a fractional polynomials of second degree.

The set of control variables includes the rate of economic growth (growth) equal to the average of the current and two lagged values of GDP growth. The three-year averages are used to smooth out business cycle fluctuations. High rates of economic growth should raise the probability of foreign financial market entry since it captures the overall profitability and solvency of domestic firms and raises the probability of debt repayment. It was mentioned, however, that in light of the pecking order theory higher profitability alleviates the need for external financing in general and foreign market entry in particular. Thus the impact of GDP growth on the probability of entry is ambiguous.

To gauge the level of domestic financial sector development the value of domestic credit to private sector in percent of GDP (findev) was used which refers to the financial resources provided to the private sector by depositary corporations. The sign of estimated coefficient on findev is a priori uncertain. On the one hand higher domestic market development lessens the liquidity constraints faced by domestic firms which, according to the pecking order theory, first tap in to domestic finance. Hence the private sector demand for external loans is inversely related to the abundance of domestic sources of financing. On the other hand a higher degree of domestic financial market development is indicative of firms' ability to establish a relationship with lenders including foreign ones. For this reason a positive sign of findev can also be expected. 
Ethnic fractionalization, labelled ethnfract, is another covariate classified as a pull factor. This variable ranges from 0 (perfectly homogeneous) to 1 (highly fragmented) and reflects the probability that two randomly selected people from a given country will belong to different ethno or ethno-religious groups. The index of ethnic fractionalization which was constructed by Fearon (2003) is expected to influence negatively the probability of entry because higher fragmentation can fuel social and political unrest and undermine foreign debt repayment.

To capture the cost differential between domestic and international financing sources two covariates were used - kaopen and inflation. The former is the Chinn-Ito (2006) de jure index measuring a country's degree of capital account openness. It can be expected that barriers to cross-border capital movements elevate the costs of foreign borrowings thereby hindering the private sector entry in the global financial market. The variable inflation is the average of current and two lagged values of the rate of change of the CPI index. Higher inflation rates translate into higher domestic nominal interest rates which increase the attractiveness of foreign borrowings. It was expected that the sign of the inflation estimated coefficient proved to be positive.

The decision to enter an international financial market is shaped by risk considerations. Both the borrower and lender are exposed to risk. The borrowers from developing and emerging countries usually obtain liabilities in foreign currencies and are thus exposed to exchange rate risk. The risk arising from fluctuations of the borrower's currency will be measured by the exchange rate stability index of Aizenman, Chinn and Ito (2013). Higher values of the variable Forex are associated with a greater exchange rate stability, lower risk and should increase the probability of private sector entry. However low exchange rate stability may be a manifestation of poor monetary policy and overall financial instability which encourages the private sector to seek external financing abroad. Hence the sign on Forex is a priori uncertain.

Borrower and lender can also be affected by risk related to the borrower's country sovereign default. The lender risk consists of financial turbulences in the borrower country produced by government insolvency which can lead to private sector insolvency. The borrower may, on the one hand, fear a rise in the costs of foreign funds due to a rise in the risk premium. On the other hand an imminent default or its aftermath can be accompanied by unstable and unfavourable conditions on the domestic financial market and induce foreign borrowing. The variable default is equal to the average value in periods $t-1$, $t$, and $t+1$ of the sovereign default dummy variable taken from Trebesch, Papaioannou and Das (2012) dataset. The average value was used because public defaults are anticipated and have long-lasting consequences which are reflected in poor credit ratings and high interest rates. The expected influence of default is uncertain as explained above. 
The sample consists of 95 emerging and developing countries in the 1970-2012 period. ${ }^{4}$ The annual data for control variables is taken, if not otherwise stated, from the World Development Indicators database compiled by the World Bank. All equations were estimated using logistic regression. Panel data estimation techniques are not used because the proportion of the total variance contributed by the panel level variance component proved to be negligible (within the range of a few tens of parts per million). However the value of standard errors robust to the clustering of observations by countries are reported.

The group of countries in the sample is heterogeneous in terms of economic, financial, and institutional development and the way in which they are perceived by the international financial markets. To account for these differences and the likely regional spillovers of risk perception the set of regressors was extended to include dummy variables for regions. The regional World Bank classification was employed and five binary variables were created: East Asia \& Pacific, Europe \& Central Asia, Latin America, Middle East \& North Africa, and South Asia. Each regional dummy variable is coded 1 only if a country belongs to a region, and otherwise is equal to 0 .

The independent variable is either bond_png_dum or bank_png_dum (see equation 1). The significance of each type of external sovereign debt was tested separately, that is one fractional polynomial function of each type of external public debt in each regression equation for the probability of private sector entry into international bonds and loans markets was included. Since each polynomial function is of second degree, there are two terms with the level of external public debt denoted with '_1' and '_2'. For instance bond_ppg_1 and bond_ppg_2 stand for the level of public debt from bonds raised to, respectively, the first and the second power, where the values of powers are guided by the deviance minimization and are reported in the bottom rows of Tables 1 and 2 under the heading of 'Best powers'. In the row entitled 'Linear vs. polynomial $p$-value' $p$-value from deviance difference between the linear model and the fractional polynomial model of second degree is provided. The estimation results for the bonds and loans markets entry are shown in Table 1 and 2.

${ }^{4}$ The list of countries in the sample: Albania; Algeria; Angola; Armenia; Azerbaijan; Bangladesh; Belarus; Benin; Bhutan; Bolivia; Botswana; Brazil; Bulgaria; Burkina Faso; Burundi; Cambodia; Cameroon; Central African Republic; Chad; China; Colombia; Congo Republic; Costa Rica; Djibouti; Dominican Republic; Ecuador; Egypt Arab Republic; El Salvador; Ethiopia; Fiji; Gabon; Gambia; Georgia; Ghana; Guatemala; Guinea; Guinea-Bissau; Guyana; Haiti; Honduras; Hungary; India; Indonesia; Iran Islamic Republic; Ivory Coast; Jamaica; Jordan; Kazakhstan; Kenya; Kyrgyz Republic; Lao PDR; Lesotho; Liberia; Madagascar; Malawi; Malaysia; Mali; Mauritania; Mauritius; Mexico; Moldova; Mongolia; Morocco; Mozambique; Myanmar; Nepal; Nicaragua; Niger; Nigeria; Pakistan; Panama; Papua New Guinea; Paraguay; Peru; Philippines; Rwanda; Senegal; Sierra Leone; South Africa; Sri Lanka; Sudan; Swaziland; Syrian Arab Republic; Tajikistan; Tanzania; Thailand; Togo; Tunisia; Turkey; Uganda; Ukraine; Venezuela, RB; Vietnam; Yemen, Republic of Zambia. 
Table 1. Fractional polynomial logistic estimates of the probability of private sector entry into the external bond market

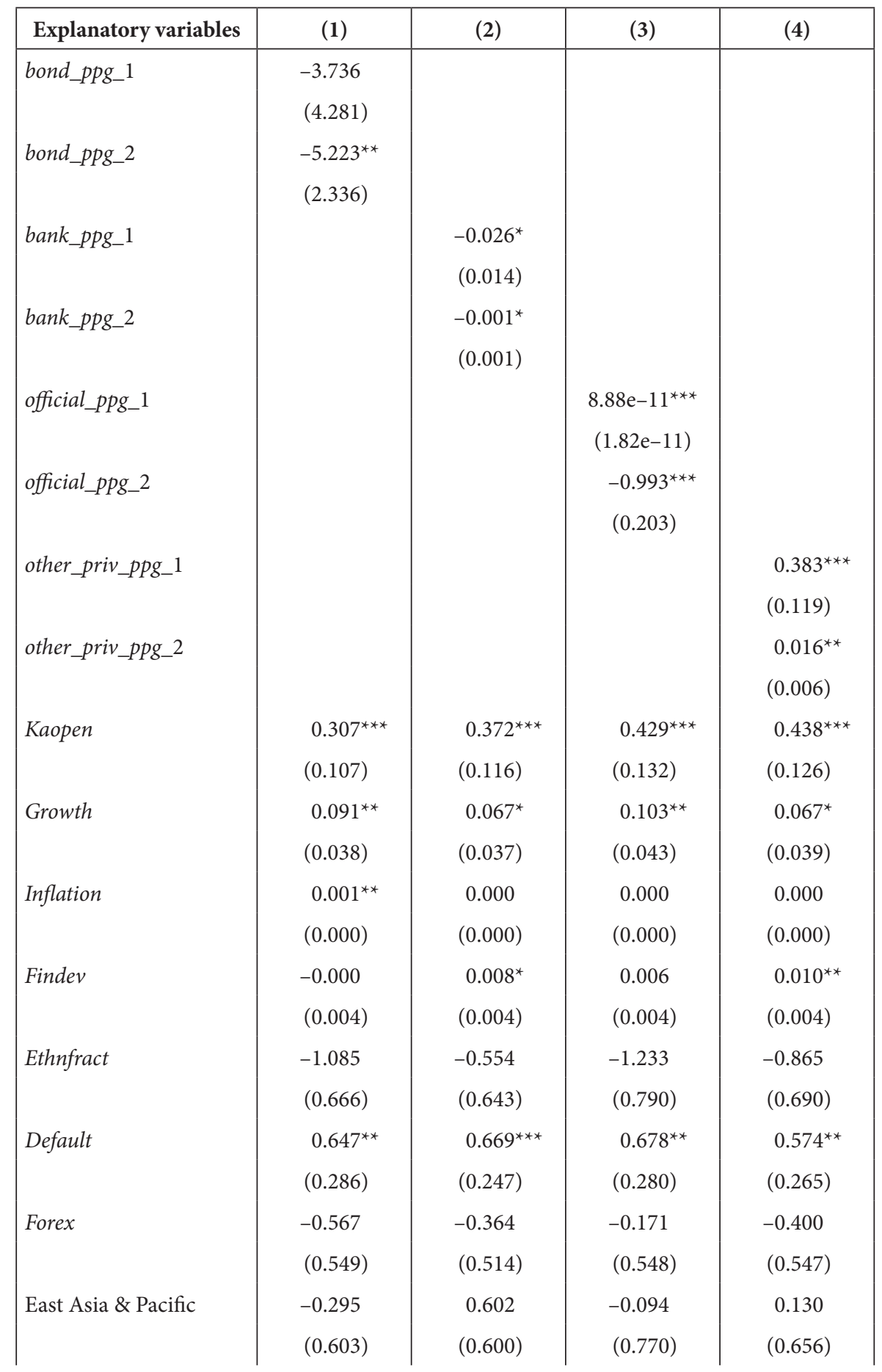




\begin{tabular}{l|c|c|c|c|} 
Europe \& Central Asia & 0.464 & $1.325^{\star}$ & 0.972 & $1.338^{\star}$ \\
& $(0.586)$ & $(0.714)$ & $(0.845)$ & $(0.696)$ \\
Latin America & -0.163 & 0.660 & 0.355 & 0.660 \\
Middle East \& North & $(0.649)$ & $(0.557)$ & $(0.667)$ & $(0.543)$ \\
Africa & -1.339 & -0.662 & $-1.933^{*}$ & -1.118 \\
& $(1.085)$ & $(0.943)$ & $(1.017)$ & $(1.003)$ \\
South Asia & $0.970^{\star}$ & $1.637^{\star * *}$ & 0.806 & $1.608^{* * *}$ \\
Constant & $(0.580)$ & $(0.567)$ & $(0.642)$ & $(0.531)$ \\
& $-3.386^{* * *}$ & $-4.868^{\star * *}$ & $-4.517^{* * *}$ & $-4.835^{* * *}$ \\
\hline Best powers & $(0.654)$ & $(0.497)$ & $(0.552)$ & $(0.457)$ \\
\hline Linear vs. polynomial & $0.5 ; 0.5$ & $-0.5 ;-0.5$ & $-2 ;-0.5$ & $0 ; 0$ \\
$p$-value & 0.00 & 0.097 & 0.001 & 0.217 \\
$N$ & 2746 & 2746 & 2746 & 2746 \\
Pseudo $R^{2}$ & 0.160 & 0.109 & 0.145 & 0.112 \\
\hline
\end{tabular}

Robust standard errors in parentheses; ${ }^{* *} p<0.01,{ }^{* *} p<0.05,{ }^{*} p<0.1$.

It can be deduced from Table 1 that capital account restrictions and, to a lesser extent, the rate of economic growth and inflation, increase the probability of private sector entry into the international bond market. The results are not robust except for the index of capital account liberalization to the inclusion of various types of external public debt. The estimated coefficient of index of ethnic fractionalization is smaller than zero and non-significant; financial development and exchange rate stability also do not seem to affect the probability of entry in the bond market. Sovereign default raises the probability of entering international financial markets pointing to disturbances in the domestic financial markets which make foreign borrowing more attractive. Only a few regional dummies are significant: European and South Asian countries are more likely to enter the international financial market.

With regards to the role of public debt it was found that all its types except for other private credits exert a non-linear influence on the probability of private sector entry into the international bond market. The non-linear impact of public debt detected in columns (1)-(3) is illustrated in Figure 1 by means of the plots of the component-plus-residual values against the levels of public debt. The component-plus-residual values are equal to the sum of deviance residual and partial linear predictors which represent the behaviour of the fractional polynomial model for respective levels of government debt and at fixed values of the remaining covariates set to equal zero. 

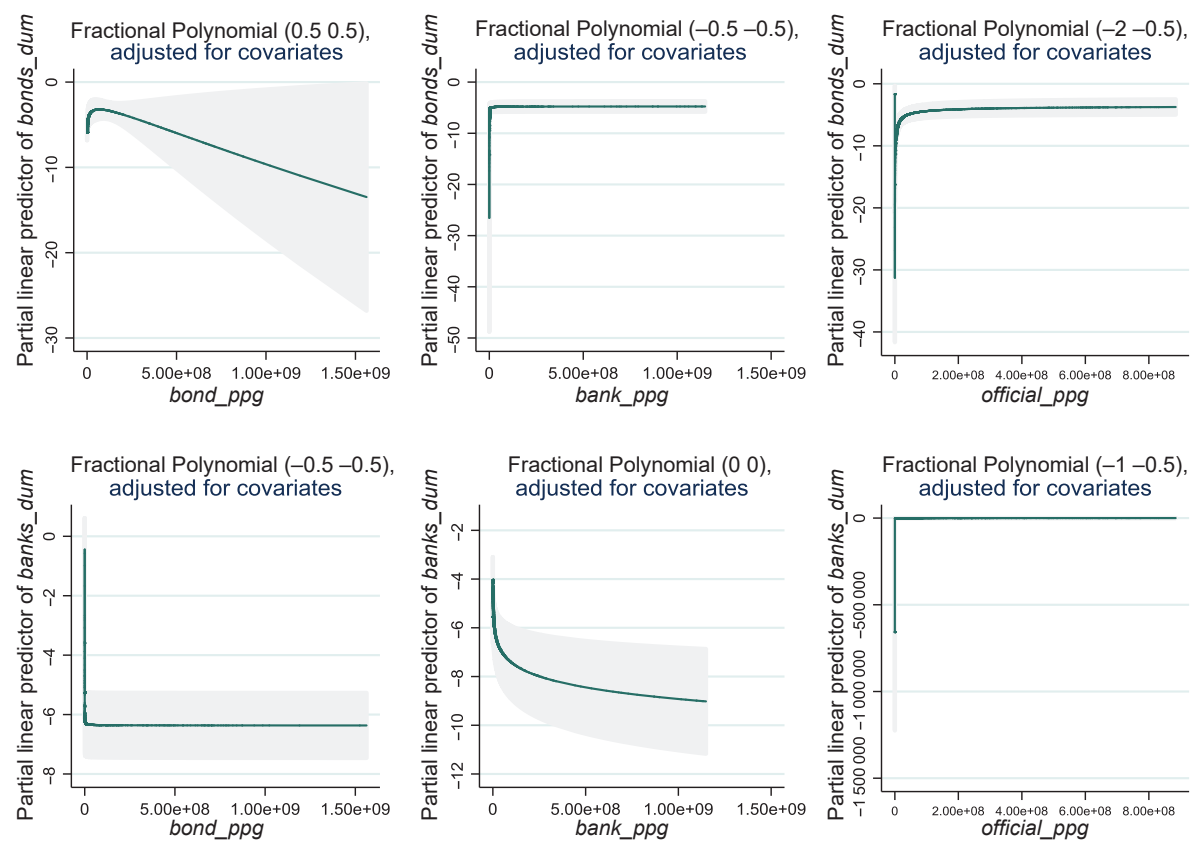

Figure 1. The fractional polynomial models fits against the levels of public debt with $95 \%$ confidence bands

The first three panels in Figure 1 reveal that public debt from bonds, loans and official creditors exerts a negative influence on the probability of private sector entry in the bond market. As public debt rises from very low levels its negative impact is moderated but it remains negative. For public debt from official creditors and banks the component-plus-residual values are not particularly sensitive to further increases in these types of public liabilities. In contrast the relationship between partial linear predictors (plus deviance residual) of bonds_dum and bond_ppg displays an inverted-U shape pointing to an increasingly binding constraint that public debt from bonds imposes on private agents attempting to enter into the bond market. An increasingly negative influence of public debt from bonds and loans on private entry into the loan market is observed in the top row of Figure 1. The impact on the probability of entry into the loan market of debt from official creditors is negative but weakening.

From column (4) of Table 1 it can be determined that the fractional polynomial model for the probability of an entry's dependence on the level of public debt from other private creditors does not fit significantly better than the linear one. Therefore the linear logistic model is estimated and the results presented in column (1) of Table 3 . It seems that, contrary to the remaining types of public external liabilities, other private credits extended to the government encourage private sector entry into the bond market. It can be argued that other private 
Table 2. Fractional polynomial logistic estimates of the probability of private sector entry into the external loans' market

\begin{tabular}{|c|c|c|c|c|}
\hline Explanatory variables & (1) & (2) & (3) & (4) \\
\hline bond_ppg_1 & $\begin{array}{l}0.005^{\star * \star} \\
(0.001)\end{array}$ & & & \\
\hline bond_ppg_2 & $\begin{array}{l}0.0002^{* * *} \\
(0.00003)\end{array}$ & & & \\
\hline$b a n k \_p p g \_1$ & & $\begin{array}{l}-0.706^{* * *} \\
(0.176)\end{array}$ & & \\
\hline bank_ppg_2 & & $\begin{array}{l}-0.026^{* * *} \\
(0.007)\end{array}$ & & \\
\hline official_ppg_1 & & & $\begin{array}{l}-0.132^{\star *} \\
(0.058)\end{array}$ & \\
\hline official_ppg_2 & & & $\begin{array}{l}1.218^{\star * *} \\
(0.446)\end{array}$ & \\
\hline other_priv_ppg_1 & & & & $\begin{array}{l}-4.914^{* * *} \\
(1.734)\end{array}$ \\
\hline other_priv_ppg_2 & & & & $\begin{array}{l}2.619^{* * *} \\
(0.981)\end{array}$ \\
\hline Kaopen & $\begin{array}{c}0.079 \\
(0.136)\end{array}$ & $\begin{array}{l}-0.052 \\
(0.136)\end{array}$ & $\begin{array}{c}0.035 \\
(0.122)\end{array}$ & $\begin{array}{l}-0.017 \\
(0.134)\end{array}$ \\
\hline Growth & $\begin{array}{l}0.093^{* *} \\
(0.041)\end{array}$ & $\begin{array}{l}0.115^{\star * *} \\
(0.037)\end{array}$ & $\begin{array}{l}0.088^{* * *} \\
(0.033)\end{array}$ & $\begin{array}{l}0.101^{\star * *} \\
(0.036)\end{array}$ \\
\hline Inflation & $\begin{array}{l}-0.001 \\
(0.001)\end{array}$ & $\begin{array}{c}0.000 \\
(0.000)\end{array}$ & $\begin{array}{r}-0.000 \\
(0.001)\end{array}$ & $\begin{array}{l}-0.000 \\
(0.000)\end{array}$ \\
\hline Findev & $\begin{array}{l}0.017^{\star * *} \\
(0.006)\end{array}$ & $\begin{array}{l}0.019^{* * *} \\
(0.007)\end{array}$ & $\begin{array}{l}0.014^{\star \star} \\
(0.006)\end{array}$ & $\begin{array}{l}0.012^{\star} \\
(0.007)\end{array}$ \\
\hline Ethnfract & $\begin{array}{l}-0.838 \\
(0.661)\end{array}$ & $\begin{array}{l}-0.900 \\
(0.650)\end{array}$ & $\begin{array}{l}-0.987 \\
(0.742)\end{array}$ & $\begin{array}{l}-0.670 \\
(0.696)\end{array}$ \\
\hline Default & $\begin{array}{l}0.764^{\star *} \\
(0.358)\end{array}$ & $\begin{array}{l}0.885^{\star *} \\
(0.386)\end{array}$ & $\begin{array}{l}0.829^{\star * *} \\
(0.321)\end{array}$ & $\begin{array}{l}0.879^{* *} \\
(0.372)\end{array}$ \\
\hline Forex & $\begin{array}{l}-0.928 \\
(0.631)\end{array}$ & $\begin{array}{l}-1.247^{\star *} \\
(0.623)\end{array}$ & $\begin{array}{l}-0.805 \\
(0.590)\end{array}$ & $\begin{array}{l}-0.932 \\
(0.593)\end{array}$ \\
\hline East Asia \& Pacific & $0.962^{*}$ & $0.958^{*}$ & $1.035^{*}$ & $0.873^{*}$ \\
\hline
\end{tabular}




\begin{tabular}{l|c|c|c|c|} 
& $(0.579)$ & $(0.504)$ & $(0.570)$ & $(0.513)$ \\
Europe \& Central Asia & $1.571^{* * *}$ & $1.135^{*}$ & $1.202^{* *}$ & $1.164^{* *}$ \\
& $(0.559)$ & $(0.584)$ & $(0.582)$ & $(0.535)$ \\
Latin America & $0.967^{\star}$ & 0.943 & 0.843 & 0.838 \\
& $(0.537)$ & $(0.605)$ & $(0.650)$ & $(0.596)$ \\
Middle East \& North & 0.762 & 0.761 & 1.068 & $1.110^{\star}$ \\
Africa & $(0.575)$ & $(0.627)$ & $(0.662)$ & $(0.606)$ \\
South Asia & 0.976 & 0.813 & $1.418^{*}$ & 0.814 \\
Constant & $(0.721)$ & $(0.716)$ & $(0.766)$ & $(0.688)$ \\
& $-6.344^{* * *}$ & $-6.685^{* * *}$ & $-6.205^{* * *}$ & $-6.235^{* * *}$ \\
\hline Best powers & $(0.556)$ & $(0.631)$ & $(0.675)$ & $(0.585)$ \\
Linear vs. polynomial & $-0.5 ;-0.5$ & $0 ; 0$ & $-1 ;-0.5$ & $0.5 ; 1$ \\
$p$-value & 0.045 & 0.004 & 0.075 & 0.107 \\
$N$ & 2746 & 2746 & 2746 & 2746 \\
Pseudo $R^{2}$ & 0.088 & 0.105 & 0.083 & 0.074 \\
\hline
\end{tabular}

Robust standard errors in parentheses; ${ }^{* *} p<0.01,{ }^{* *} p<0.05,{ }^{*} p<0.1$.

credits from manufacturers, exporters and other suppliers of goods and bank credits covered by a guarantee of an export credit agency are not determined by a portfolio consideration that motivated the hypothesis of non-linear association between public debt and private sector entry.

To assess a pattern of the relationship between public debts and the private sector entry in the international loans market fractional polynomial logistic regressions were run and the result is shown in Table 2. There is not much similarity between the determinants of entry into the loan and bond market. Ethnic fractionalization seems to discourage the private sector from seeking sources of finance from foreign banks but this result is not statistically significant. The degree of domestic financial development, economic growth and defaults were found to increase the probability of entering the international loan market. Restrictions on free capital movements and inflation do not shape the private sector's decision to enter the loans' market. Exchange rate stability reduces the entry probability only if the model checks the level of public debt in the form of loans.

The level of public external debt has a complex effect on the probability of private sector entry into the international loans' market. Public debt from other private creditors and private sector entry into that loan segment of the international financial market are linearly connected. When the level of pub- 
Table 3. Logistic estimates of the probability of private sector entry into the external bonds (column 1) and loans (column 2) markets

\begin{tabular}{|c|c|c|}
\hline Dependent variable & bonds_dum & banks_dum \\
\hline Explanatory variables & (1) & (2) \\
\hline \multicolumn{3}{|l|}{ bond_ppg } \\
\hline \multicolumn{3}{|l|}{ official_ppg } \\
\hline \multirow[t]{2}{*}{ other_priv_ppg } & $7.42 \mathrm{e}-09^{* * *}$ & $-5.67 e-09$ \\
\hline & $(1.82 \mathrm{e}-09)$ & $(8.66 \mathrm{e}-09)$ \\
\hline \multirow[t]{2}{*}{ Kaopen } & $0.363^{* * *}$ & 0.068 \\
\hline & $(0.115)$ & $(0.142)$ \\
\hline \multirow[t]{2}{*}{ Growth } & 0.061 & $0.100^{* * *}$ \\
\hline & $(0.042)$ & $(0.036)$ \\
\hline \multirow[t]{2}{*}{ Inflation } & 0.000 & -0.000 \\
\hline & $(0.000)$ & $(0.001)$ \\
\hline \multirow[t]{2}{*}{ Findev } & $0.010^{\star *}$ & 0.010 \\
\hline & $(0.005)$ & $(0.007)$ \\
\hline \multirow[t]{2}{*}{ Ethnfract } & -0.278 & -0.954 \\
\hline & $(0.671)$ & $(0.691)$ \\
\hline \multirow[t]{2}{*}{ Default } & $0.648^{\star \star}$ & $0.698^{\star *}$ \\
\hline & $(0.271)$ & $(0.349)$ \\
\hline \multirow[t]{2}{*}{ Forex } & -0.656 & -0.694 \\
\hline & $(0.521)$ & $(0.579)$ \\
\hline \multirow[t]{2}{*}{ East Asia \& Pacific } & 0.669 & 0.567 \\
\hline & $(0.584)$ & $(0.579)$ \\
\hline \multirow[t]{2}{*}{ Europe \& Central Asia } & $1.575^{\star *}$ & $1.017^{\star}$ \\
\hline & $(0.644)$ & $(0.546)$ \\
\hline \multirow[t]{2}{*}{ Latin America } & $1.032^{*}$ & 0.498 \\
\hline & $(0.538)$ & $(0.578)$ \\
\hline \multirow[t]{2}{*}{ Middle East \& North Africa } & -0.525 & 0.447 \\
\hline & $(1.024)$ & $(0.616)$ \\
\hline \multirow[t]{2}{*}{ South Asia } & $1.863^{* * *}$ & 0.621 \\
\hline & $(0.578)$ & $(0.690)$ \\
\hline \multirow[t]{2}{*}{ Constant } & $-5.492^{\star \star \star}$ & $-4.953^{\star \star \star}$ \\
\hline & $(0.710)$ & $(0.729)$ \\
\hline$N$ & 2746 & 2746 \\
\hline Pseudo $R^{2}$ & 0.100 & 0.055 \\
\hline
\end{tabular}

Robust standard errors in parentheses; ${ }^{* *} p<0.01,{ }^{* *} p<0.05,{ }^{*} p<0.1$. 
lic debt from loans is entered as a linear term in the model it is found to be an insignificant predictor of the private sector entry in the external loan market.

The impact of public debt for other creditors was therefore estimated with the help of a logistic regression model. The results are reported in column (2) of Table 3. The relationship between private entry into the loan market and other types of government debt is illustrated in the bottom row of Figure 1 and as shown in columns (1)-(3) of Table 2, an increase in the public debt from loans and bonds, respectively, reduces and increases the probability of entry at a decreasing rate.

The analysis of the interplay between external public and private debt proved that there are different factors behind the initial participation in the external bond and loan market. It is noteworthy that the relationship between private sector entry into the bond and loan markets and public external debt displays a complex pattern. It is usually negative, except for the entry into loans market and its dependence on public debt from bonds which was found positive. The relationship between private sector entry into the market and public sector borrowing is in most cases best described with the aid of fractional polynomial functions.

It was concluded that a saturation of the financial market with external government liabilities renders the private sector entry into the bond market more difficult. The reputation enhancing effect of public debt is far less pronounced because it was found that only public debt from bonds gives a boost to entry into the international loans market.

\section{Conclusions}

Using data on 95 emerging and developing countries over the 1970-2012 period the determinants of private sector entry in the foreign bond and loan markets focusing on the role played by various types of public external debt were investigated and. several interesting conclusions were reached.

First it was revealed that the stock of public external debt from bonds harms the chances of private sector entry in that segment of the international financial market. Second, the probability of first issuance of private sector bonds in international financial markets is also reduced by public bank loans. Surprisingly, the stock of public debt from other private creditors seems to encourage private sector entry in the bond market. The complex non-linear relationship between various types of public external debt and private sector entry into the bond market can be captured by means of the fractional polynomial function.

Third, the stock of public external debt from loans dampens the willingness of banks to establish private sector credit for the first time, while the opposite holds true for public external debt from bonds. Other types of sovereign liabili- 
ties display a complex non-linear relationship with private sector entry into the loan market. Generally public borrowing crowds-out private borrowing in the same segment of the international financial market (i.e., bond or loan market) and public bonds crowd-in private loans. In terms of policy recommendations, these findings suggest that public sector debt from other private creditors has the least negative spillover effects on the private sector presence in the international financial market.

An interesting way forward for future research is to assess the impact of the level, structure and currency composition of external public debt on the volume and currency composition of private external debt.

\section{References}

Aabo, T. (2006). The importance of corporate foreign debt in managing exchange rate exposures in non-financial companies. European Financial Management, 12, 633-649. Aizenman, J., Chinn, M. D., \& Ito, H. (2013). The 'Impossible Trinity' hypothesis in an era of global imbalances: measurement and testing, Review of International Economics, 21(3), 447-458.

Allayannis, G., Brown, G. \& Klapper, L. (2003). Capital structure and financial risk: evidence from foreign debt use in East Asia. Journal of Finance, 58, 2667-2709.

Allayannis, G., \& Ofek, E. (2001). Exchange rate exposure, hedging and the use of foreign currency derivatives. Journal of International Money and Finance, 20, 273-296.

Augustin, P., Boustanifar, H., Breckenfelder, J., \& Schnitzler, J. (2016). Sovereign to corporate risk spillovers (ECB Working Paper No. 1878). Frankfurt am Main: European Central Bank.

Brzozowski, M., \& Siwińska-Gorzelak, J. (2016). The interplay between public and private external debt stocks. International Finance, 19(3), 311-332.

Cavallo, E. A., \& Valenzuela, P. (2010). The determinants of corporate risk in emerging markets: an option-adjusted spread analysis. International Journal of Finance \& Economics, 15, 59-74.

Chinn, M. D., \& Ito, H. (2006). What matters for financial development? Capital controls, institutions, and interactions. Journal of Development Economics, 81(1), 163-192 .

Das, U., Papaioannou, M., \& Trebesch, C. (2010). Sovereign default risk and private sector access to capital in emerging markets (IMF Working Paper No. 10/10). Washington: International Monetary Fund.

Esteves, R., \& Jalles, J. (2016). Like father like sons? The cost of sovereign defaults in reduced credit to the private sector. Journal of Money, Credit and Banking, 48(7), 1515-1545.

Fearon, J. D. (2003). Ethnic and cultural diversity by country. Journal of Economic Growth, 8(2), 195-222.

Garcia-Herrero, A., \& Martinez-Peria, M. S. (2005). The mix of international banks foreign claims: determinants and implications for financial stability (Working Paper No. 525). Bank of Spain. 
Goldberg, L. (2001). When is US lending to emerging markets volatile? (Working Paper No. 8209). Cambridge, Ma: National Bureau of Economic Research.

Gozzi, J., Levine, R., Peria, M., \& Schmukler, S. (2015). How firms use corporate bond markets under financial globalization. Journal of Banking \& Finance, 58, 532-551.

Habib, M., \& Joy, M. (2010). Foreign-currency bonds: currency choice and the role of uncovered and covered interest parity. Applied Financial Economics, 20, 601-626.

Hernandez, L., Mellado, P., \& Valdés, R. (2001). Determinants of private capital flows in the 1970s and 1990s: is there evidence of contagion? (Working Paper No. 64). Washington: International Monetary Fund.

Herrmann, S., \& Mihajlek, D. (2010). The determinants of cross-border bank flows to emerging markets: new empirical evidence on the spread of financial crises (Deutsche Bundesbank Discussion Paper Series 1: Economic Studies No. 17).

Jeanneau, S., \& Micu, M. (2002). Determinants of international bank lending to emerging market economies (Working Paper No. 112). Basel: Bank for International Settlements.

Keloharju, M., \& Niskanen, M. (2001). Why do firms raise foreign currency denominated debt? Evidence from Finland. European Financial Management, 7, 481-496.

Mizen, P., Packer, F., Remolona, E., \& Tsoukas, S. (2012). Why do firms issue abroad? Lessons from onshore and offshore corporate bond finance in Asian emerging markets. Basel: Bank for International Settlements, Monetary and Economic Department.

Mohapatra, S., Nose, M., \& Ratha, D. (2017). Determinants of the distance between sovereign credit ratings and sub-sovereign bond ratings: evidence from emerging markets and developing economies. Applied Economics, 50(9), 934-956.

Myers, S., \& Majluf, N. (1984). Corporate financing and investment decisions when firms have information investors do not have. Journal of Financial Economics, 131, 187-221.

Royston, P., \& Sauerbrei, W. (2008). Multivariable model-building: a pragmatic approach to regression analysis based on fractional polynomials for modelling continuous variables. New York: Wiley Series in Probability and Statistics.

Trebesch, C., Papaioannou, M. G., \& Das, U. S. (2012). Sovereign debt restructurings 1950-2010: literature survey, data, and stylized facts (IMF Working Paper No. 203). Washington: International Monetary Fund. 